\title{
LIM Domain-Containing Protein Ajuba
}

National Cancer Institute

\section{Source}

National Cancer Institute. LIM Domain-Containing Protein Ajuba. NCI Thesaurus. Code C115438.

LIM domain-containing protein ajuba (538 aa, $\sim 57 \mathrm{kDa}$ ) is encoded by the human AJUBA gene. This protein plays a role in the formation of protein complexes. 